\title{
Sea Transportation Network Development of the Liukang Tangayya Islands
}

\author{
Chairunnisa Mappangara \\ Department of Naval Architecture \\ Hasanuddin University \\ Gowa, Indonesia \\ andi.chairunnisa@yahoo.co.id \\ Syamsul Asri \\ Department of Naval Architecture \\ Hasanuddin University \\ Gowa, Indonesia \\ satanrikapal83@yahoo.com
}

\author{
Lukman Bochary \\ Department of Naval Architecture \\ Hasanuddin University \\ Gowa, Indonesia \\ lukmanbocha56@gmail.com \\ M. Rizal Firmansyah \\ Department of Naval Architecture \\ Hasanuddin University \\ Gowa, Indonesia \\ mr.firmansyah@gmail.com
}

\begin{abstract}
One of the archipelago subdistrict in the Pangkep Regency is Liukang Tangayya District with an area of $11,960 \mathrm{~km} 2$ which consists of approximately 55 large and small islands. Connectivity between regions can be improved by providing adequate and reliable transportation facilities and infrastructure, as well as efficient operation that will have an impact on economic growth, equity and sustainability to reduce growth gaps and disparities in Wellbeing between regions. The determination hierarchy of the islands contained in the Liukang Tangayya subdistrict is carried out to identify potential islands as hubs of the sea transportation network within the respective island clusters. The islands contained in the island cluster area of Liukang Tangayya Subdistrict from their geographical position are grouped into 3 (three) small island zone groups namely the first zone with Sapuka Lompo Island as the economic center, the second zone with the service center on Matalaang Island and the third zone with the service center on Sailus Lompo Island. The recommended capacity of the people transport fleet to serve the route network in the cluster of islands is around 5 - 15 GT. Meanwhile, the main route connecting the island cluster centers with the main activity center in the provincial capital will still be served by pioneer transportation.
\end{abstract}

Keywords: connectivity, sea transportation, island cluster

\section{INTRODUCTION}

Strengthening connectivity is an effort to achieve the well-being of the Indonesian people as contained in the Master Plan for the Acceleration and Expansion of Indonesia's Economic Development (MP3EI) 2011 - 2025 [1]. Weak connectivity can be seen by the concentration of economic activity in urban areas and industrial activities that do not extend to underdeveloped and isolated areas due to limited transportation infrastructure [2]. Connectivity between regions can be improved by providing adequate and reliable transport facilities and infrastructure, as well as efficient operation to improve industrial access from processing centers to commercialization areas 3]. Strengthening connectivity will have an impact on economic growth, equity and sustainability to reduce growth disparities and welfare inequalities between regions [4].

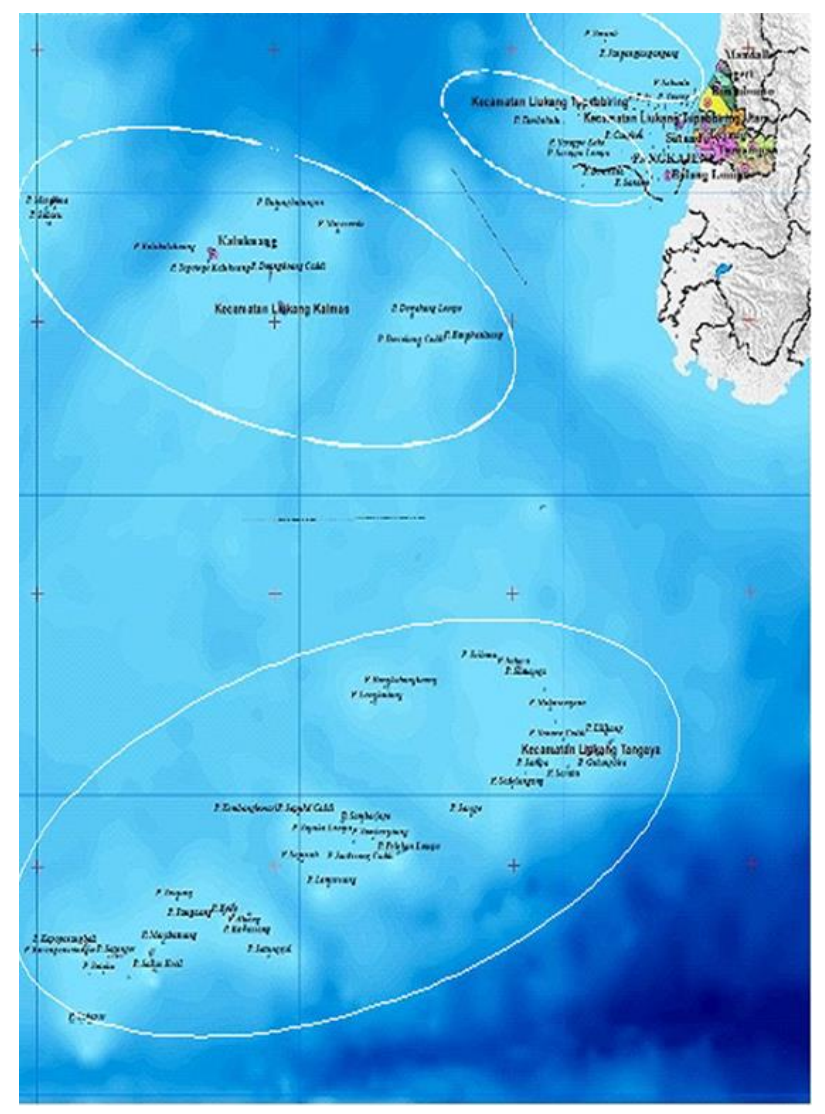

Fig. 1. Map of the Pangkep Regency Island Cluster Area.

Pangkajene and Kepulauan Regency are located on the west coast of the South Sulawesi province. Geographically, Pangkajene Regency and Archipelago consist of land and islands that require the support of the maritime transport network to improve connectivity between regional growth centers and local growth centers, especially those on the islands, as shown in Fig. 1. One of the islands in the Pangkep regency is the Liukang Tangayya district with an area of $11,960 \mathrm{~km} 2$ consisting of approximately 55 large and small islands. The Liukang Tangayya sub-district borders Selayar Regency in the east, NTB Province in the south and East Java Province in the west. The capital of 


\section{B. Island Hierarchy in the Archipelago of Liukang} Tangayya Subdistrict

One approach to optimizing a transport network system is to build a hierarchical network. The advantages of the hierarchical model include: economies of scale on highfrequency routes, economies of scale in regional activity centers (cars) for the development of car potential. And in Sistranas [6] it was noted that the organization of a transport system takes into account the structure of the Economic Service Center, the Government Service Center and the Service Center.

The purpose of identifying the island hierarchy in the Liukang Tangayya District is to identify the islands that are likely to become the hub of the shipping network within each archipelago. The hierarchy is organized according to the facilities available on the island, the socio-economic potential and the available port infrastructures [7].

The islands in the archipelago area of Liukang Tangayya District can be divided into 3 (three) small groups of island areas from their geographical location.

- The first Sapuka Lompo Island area as a business center with service islands, namely Kambang Lamari Island and Stayingugan Island.

Continental Pangkep region as the dessert of the Iles group. Infrastructures include Pangkajene, Baji Maccini, Kassi Kebo, Jennae, Pangkep Poros, Pungkalawaki and Bawasalo Kalukue. The regions Liukang Tangayya, Sapuka, Balobaloang, Langkoitang, Matalaang and Bali Kapoposang are displayed.

The shipping network connecting island cluster region the Liukang Tangayya District with Regency Capital is KM Papa Dua with navigation routes over the islands Pangkep Regency, namely Makassar - Maccini Baji Balang Island Lompo - Balo Baloang Island Lompo Matalaang P. Island - Sapuka Lompo Island - Lompo Lompo Island - Badas / Khayangan - P. Sailus Lompo Island - P Sapuka Lompo - Matalaang P. - Balobaloang P. Lompo - Balang Lompo P. - Maccini Baji - Makassar, as shown in Fig. 2 and Fig. 3.

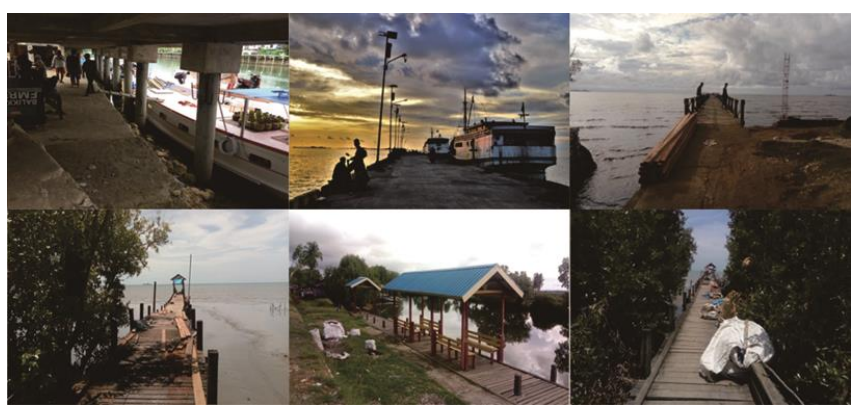

Fig. 2. Berth Infrastructure in the Mainland Area of Pangkep Regency.

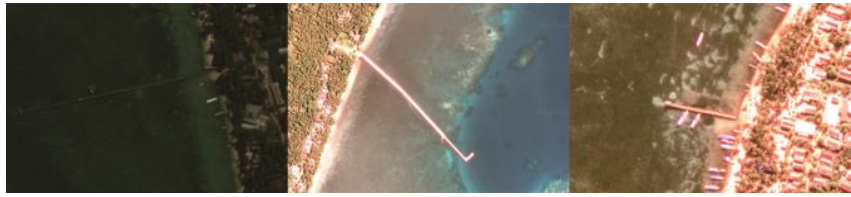

Fig. 3. Berth Infrastructure in the Island Cluster Area of Liukang Tangayya District.
- The second area with a service center on Matalaang Island serving Sabalana Island, Sanane Island, Makarangani Island, Lilikang Island, Pammolikang Island, Sabaru Island and Baloang Island, Sumane Island, Sanane Island, Sanipa Island, Pelokang Island and Langkuitang Island.

The third area with a service center on the island of Sailus Lompo serving the islands of Sailus Kecil, Marabatuang, Kawassang, Makarangan, View Island and Tampaang. Aloang Island, Sapinggang Island, Kapoposang Island Bali and Satanger Island.

\section{IDENTIFICATION OF THE MARITIME TRANSPORT NETWORK}

The hierarchy of the Liukang Tangayya sub-district infrastructure network has been established in the RIPN, namely the ports of Sapuka Island and Sailus Island as harbors. While the ports of Balo-baloang Lompo, Langkoitang Island, Kapoposang Island on Bali and Matalaang Island are included as ports in the RIPN port location and hierarchy plan. Premises.

The Liukang Tangayya Island Group's shipping network consists of distribution networks that are linked as local network centers to business centers. There are three (3) local hubs, namely Matalaang Port, Sapuka Lompo Port and Sailus Port. The power grid is as follows:

- Sabaru Tangayya Island - Balobaloang Lompo Island Balobaloang Kecil Island - Sumanga Island Makaragana Island - Matalaang Island

- Lilikang Island - Sabalana Island - Sanane Island Matalaang Island

- Pelokang Island - Matalaang Island 


\section{CONCLUSIONS}

Islands in the archipelago of Liukang Tangayya District can be divided into three (3) small groups of island regions due to their geographical location. The islands of Kambang Lamari and Stayingugan are the first areas where the island of Sapuka Lompo is the center of the economic and service islands. The second area with a service center on the island of Matalaang serves the islands of Sabalana, Sanane, Makarangani, Lilikang, Pammolikang, Sabaru and Baloang Sumanga Island, Sanane Island, Sanipa Island, Pelokang Island and Langkuitang Island. The third area with a service center on Sailus Lompo Island serving Sailus Kecil Island, Marabatuang Island, Kawassang Island, Makarangan Island, Island View, Tampaang Island, Aloang Island, Sapinggang Island, Kapoposang Island Bali and Satanger Island.

Recommended network route specifications and fleet capacity are as follows:

- Island Sabaru Tangayya - Island Balobaloang Lompo Island Balobaloang - Island Sumanga - Island Makaragana - Island Matalaang is served by a Pelra fleet with a capacity of 10-15 GT.

- $\quad$ Lilikang Island - Sabalana Island - Sanane Island Matalaang Island is served by a Pelra fleet with a capacity of 10-15 GT

- Pelokang Island - Matalaang Island served by a Pelra fleet with a capacity of 10-15 GT

- $\quad$ Langkotang Island - Sanipa Island - Matalaang Island is served by a Pelra fleet with a capacity of 10-15 GT

Connectivity between the three hub ports of Liukang Tangayya Island Group is currently connected through an innovative transport network across the three hubs. The main current transport routes are: Port Baji Maccini Balobaloang Island Lompo - Matalaang Island - Sapuka Lompo Island - Sailus Island Lompo - NTB Badas Harbor (pp).

\section{FLeET NEEDS ANALysis}

In the Liukang Tangayya island region for road networks:

- Island Sabaru Tangayya - Island Balobaloang Lompo Island Balobaloang - Island Sumanga - Island Makaragana - Island Matalaang, Island Lilikang Island Sabalana - Island Sanane - Island Matalaang, each with a fleet of 10-15 GT.

- Pelokang Island - Matalaang Island, Langkotang Island - Sanipa Island - Matalaang Island, Kambang Lemari Island - Residence Island - Sapuka Lompo Island, Kapoposang Island Bali - Satanger Island - Sailus Lompo Island, Tampa Island - Pandangan Island Makarangan Island - Marabatuang Island - Sailus Lompo Island, Kawassang Island - Sapinggan Island Aloang Island - Sailus Lompo Island each served by a fleet of size 5-10 GT.

- Sailus Kecil Island - Sailus Lompo Island is served by a fleet of 2 - 5 GT.
- Kambang Lemari Island - Tinggalungan Island Sapuka Lompo Island is served by a Pelra fleet with a capacity of 10-15 GT

- Kapoposang Bali Island - Satanger Island - Sailus Lompo Island is served by a Pelra fleet with a capacity of 10-15 GT

- $\quad$ Tampa Island - Pandangan Island - Makarangan Island - Marabatuang Island - Sailus Lompo is served by a Pelra fleet with a capacity of 10-15 GT

- Kawassang Island - Sapinggan Island - Aloang Island Sailus Lompo Island is served by a Pelra fleet with a capacity of 10-15 GT

- $\quad$ Sailus Kecil Island - Sailus Lompo Island is served by a Pelra fleet with a capacity of 10-15 GT

\section{REFERENCES}

[1] Presidential Regulation Number 48 of 2014. About Masterplan for the Acceleration and Expansion of Indonesia's Economic Development 2011 - 2025 (in Indonesian).

[2] Morlok, E. K., 1985. Introduction to Transportation Planning Techniques (in Indonesian). Translation by Hainin, J.K., Erlangga, Jakarta.

[3] Decision of the Director General of Sea Transportation Number UK.11/15/15/DJPL-06. About Blue Print of Sea Transportation 2005 - 2024 (in Indonesian).

[4] Adisasmita, S.Adji., 2011. Transportation and Area Development (in Indonesian). Graha. Adisasmita, S.Adji., 2011. Transportation Network Theory and Analysis. Graha Ilmu. 
[5] Regional Regulation Number 8 of 2012 concerning Regional Spatial Planning (RTRW) of Pangkajene and Kepulauan Regency (in Indonesian).

[6] Sitepu, Ganding (2008), Structuring the Port Hierarchy in the Island Group of Disadvantage Regions in Southern Sulawesi (in Indonesian). Journal of Transportation, Vol. 8, Number 2 December 2008.

[7] Sihaloho, Antonius. 2012. The Tran Maluku Islands Group Transportation Model in Supporting the Development of the Maluku Province Region (in Indonesian). Dissertation Hasanuddin University Postgraduate Program. Makassar. 